American Journal of Environmental Sciences 6 (6): 505-515, 2010

ISSN 1553-345X

(C) 2010 Science Publications

\title{
Oil Refineries Emissions Impact on Urban Localities Using AERMOD
}

\author{
${ }^{1}$ Amira Mohamed Wahba Abdelrasoul, ${ }^{1}$ Amir AL-Hadad and ${ }^{2}$ Abdul Rehman Khan \\ ${ }^{1}$ Department of the Chemical Engineering, \\ Kuwait University, P.O. Box 5969, Safat 13060, Kuwait \\ ${ }^{2}$ Researcher at Environmental and Urban Development Division, \\ Kuwait Institute for Scientific Research, P O Box 24885, Safat 13109, Kuwait
}

\begin{abstract}
Problem statement: The absolute necessity of compulsory fuel utilities, no matter small or big has resulted into substantial high hazards pollutants. Petroleum refineries are major industrial installations that are necessary for providing the best suited fuel for various necessary utilities, but are responsible of the emission of several hazardous pollutants into the atmosphere. Hydrocarbons are among the most perilous air pollutants that are emitted from almost all refining processes in petroleum refineries. Approach: Every day leaks and gaseous discharge from relief valves and liquid discharge, which are often directed to knock-out drums, are flared to minimize the impact of hydrocarbons emissions. But these flares are not that efficient and result into partial discharge of pollutants that have severe impact on the industrial area and urban localities in the vicinity of industrial refining complex. Results: In the present study, a thorough investigation has been completed to estimate the total emissions of sulfur dioxide $\mathrm{SO}_{2}$ and non methane hydrocarbons NMHC (VOCs) and to assess their impact on the air quality in industrial and suburban areas. The latest version AMS/EPA Regulatory Model (AERMOD) specially designed to support the US Environmental Protection Agency (EPA)'s was used to predict the ground level concentrations of $\mathrm{SO}_{2}$, VOCs from AL-Ahmadi and Al-Shuiba Refineries of total refining capacity of 646 thousand barrels/day. Conclusion/Recommendations: These concentrations are compared with EPA standards to indicate the ambient air quality. The dispersion model was corroborated with extensive one year hourly record of the surface and upper air meteorological data for year 2006 and emission rates of the specified pollutants, with detailed refinery stacks parameters, such as stack height, diameter, exit flue gas velocity and temperature to determine the fraction of total study area in the vicinity of refineries that had substantially high concentration of these pollutants. It's found that $10 \%$ of selected area under study has exceedance for $\mathrm{SO}_{2}, 13 \%$ exceedance for non-methane hydrocarbons NMHC, and there is no exceedance for $\mathrm{NO}_{2}$ which is considered about $50 \%$ of total NOx emissions.
\end{abstract}

Key words: Hydrogen sulfide, Volatile Organic Compound (VOC), meteorological parameters, sulfur dioxide, Environmental Protection Agency (EPA), Industrial Source Complex (ISC), urban localities, oil refineries, AMS/EPA Regulatory Model (AERMOD)

\section{INTRODUCTION}

Air pollution is a major problem that has been recognized throughout the world for almost a century. The lifestyle that we take for granted is made possible through the usage of the fuels (i.e., LPG, motor gasoline, diesel fuels, jet fuels, aviation gasoline, heating oil's, heavy fuel oils,) and specialty products (i.e., lubricants, waxes, asphalts and solvents), as well as the petrochemical industry feed stocks produced by the petroleum refining industry from associated gas and crude oils. The petroleum refineries and petrochemical plants are the largest sources of air pollution in the region. Their operation is associated with the emission of various organic compounds into the atmosphere. (Cetin et al., 2003; Al-Hamad et al., 2008).

The flare system is designed to provide safe receipt and disposal of unwanted, toxic gases/vapors released from process equipment during normal operations to minimize the impact of emissions, but these flares are not that efficient and result into partial discharge of hydrocarbons and other emissions of carbon dioxide, carbon monoxide, NOx and SOx at

Corresponding Author: A.W. Abdelrasoul, Department of the Chemical Engineering, Kuwait University, P.O. Box 5969, Safat 13060, Kuwait 
elevated temperature that have severe influence on the industrial area and urban localities in the vicinity of industrial refining complex.

The most two controversial pollutants are $\mathrm{SO}_{2}$ and NMHC. These atmospheric pollutants once emitted into the atmosphere may cause a pollution problem on local scale and a major health risk to the population in the urban areas in the vicinity of oil installation. The regional problem like acid rain or photochemical ozone production in the troposphere initiated by the reaction of hydrocarbons with $\mathrm{OH}$ radicals in the presence of nitrogen oxides and sunlight originate smog and visibility problems. (Kalabokas et al., 2001; Ramadan et al., 2008).

Most of the Hydrocarbons emitted by Petroleum refineries play major role in the physicochemical processes of the troposphere as they largely contribute to the formation of ozone and other photochemical oxidants (Kalabokas et al., 2001). Moreover, some hydrocarbons are highly toxic or carcinogenic. Hydrocarbon are also generated as a result of human activities, arising mainly from motor vehicle exhausts and other combustion processes utilizing fossil fuels, petrol storage and distribution, solvent usage and other industrial processes(Al-Hamad et al.,2008).

Sulfur dioxide causes a wide variety of health risk and its environmental impact has been known as acid rain over a century. Particularly sensitive groups include people with asthma who are active outdoors and children, the elderly with heart or lung diseases. $\mathrm{SO}_{2}$ and the other associated pollutants such as sulfate particles can be transported over long distances and deposited far from the point of origin. This means that problems with $\mathrm{SO}_{2}$ are not confined to areas where it is emitted (AlJahdali and Bisher, 2008).

\section{MATERIALS AND METHODS}

The aim of the present study is the determination of atmospheric pollution levels, a thorough investigation has been completed to estimate the total emissions of $\mathrm{SO}_{2}$ and VOCsandassess their impact in the air quality in industrial and suburban areas. The latest version AMS/EPA Regulatory Model (AERMOD) (Venkatram et al., 2004) specially designed to support the US Environmental Protection Agency (EPA)'s was used to predict the ground level concentrations of $\mathrm{SO}_{2}$, NMHC from AL-Ahmadi and Al-Shuiba Refineries of total refining capacity of 646 thousand barrels/day. The dispersion model was corroborated with extensive one year hourly record of the surface and upper air meteorological data for year 2006 and emission rates of the specified pollutants, with detailed refinery stack parameters, such as stack height, diameter, exit flue gas velocity and temperature to determine the ground level concentrations of $\mathrm{SO} 2$ and $\mathrm{NMHC}$ and assess the fraction of the total study area under exceedence of EPA standards.

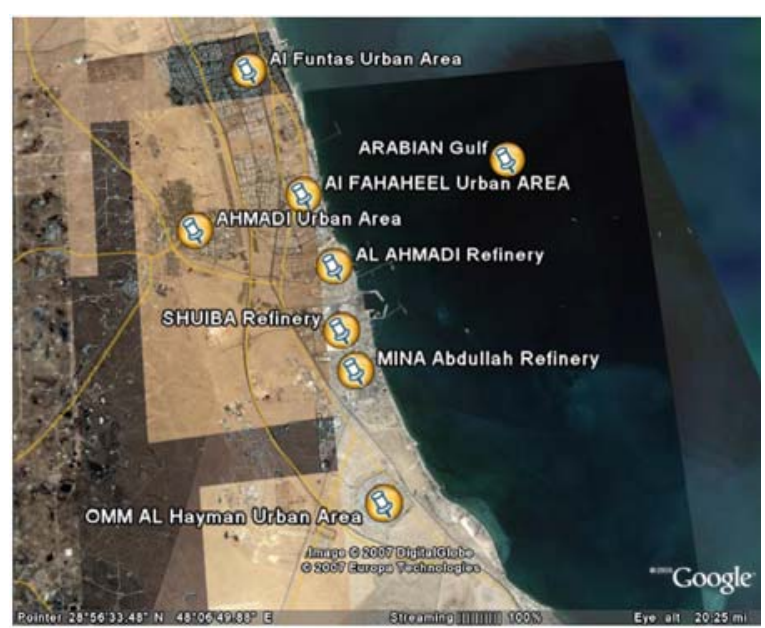

Fig. 1: Satellite image showing urban areas in the vicinity of oil refineries

Area description under investigation: The area under study in this study covers the oil refinery areas in the state of Kuwait. Kuwait is surrounded by hot deserts in the north, west and south and in the east it is bordered by sea. Kuwait has the third largest oil reserves in the world after Saudi Arabia and Iraq. The oil reserve of Kuwait is estimated to around $10 \%$ of the total world reserve. The production capacity of Kuwait's refineries altogether amounts to approximately 936 thousand barrels/day, distribute as follows: Mina Ahmadi Refinery (446 thousand barrels/day) consists of four flaring stacks (MAFP, FUP, RMP and OR), Shuaiba Refinery (200 thousand barrels/day) has two identical flares in all respect (ST29-01 and ST29-02) And Mina Abdulla Refinery (470 thousand barrels/day).

The urban areas surrounding oil refineries are Fahaheel, Ahmadi and Omm Hayman Areas as shown in Fig. 1. These urban areas include all the human facilities like schools, hospitals, hotels, shopping mallsandrecreational activities in clubs and stadiums .The receptor grid specified covers an area of $500 \mathrm{~km}^{2}$ keeping the predominant emission sources in the center.

An average composition of Kuwaiti crude oil is $2.44 \%$ by weight Sulfur, $0.14 \%$ Nitrogen, $7.7 \mathrm{ppm}$ Nickel, $28 \mathrm{ppm}$ Vanadium, 22.7\% Naphtha fraction (boiling pt. from $20-205^{\circ} \mathrm{C}$ ) , $77.3 \%$ High boiling fraction (boiling pt. above $205^{\circ} \mathrm{C}$ ), $23.3 \%$ Aromatics, $20.9 \%$ Paraffin and $3.5 \%$ Insoluble. That's refined to produce various types of fuels for domestic and industrial use. The total emissions for oil refinery facilities are mainly from boilers, fired heaters, hydrogen reforming, hydro-cracking, hydro-treating, hydro-desulphurization units and other distillation processes. 
Model application: For this purpose, The AMS/EPA Regulatory Model (AERMOD) specially designed to support EPA's regulatory modeling programs. AERMOD is regulatory steady state plume modeling system with three separate components: AERMOD (AERMIC Dispersion Model), AERMAP (AERMOD Terrain Preprocessor) and AERMET (AERMOD Meteorological Preprocessor). The AERMOD model includes a wide range options for modeling air quality impacts of pollution sources, making it popular choice among the modeling community for a variety of applications. (Holmes and Morawska, 2006).

AERMOD has an improved approach for characterizing the fundamental boundary layer parameters and vertical profile of the atmosphere along with better representation of plume buoyancy, penetration and urban nighttime boundary layer, it provides variable urban treatment of vertical dispersion as a function of city populations as compared to Industrial Source Complex (ISC) which is mainly limited to regulatory purposed. (Kesarkar et al., 2007; Abdul-Wahba et al., 2002).

The input data that describe both emission source such as pollutant emission rate $\left(\mathrm{gs}^{-1}\right)$; Base elevation from sea level (m); Stack height (m); Stack coordinate location; Exit stack inner diameter (m); Exit stack gas speed $\left(\mathrm{ms}^{-1}\right)$; and Exit stack gas temperature $(\mathrm{K})$; and meteorology provide a comprehensive set of information which can be used to run AERMOD model and thus simulate the ground level concentration of the pollutants.

Meteorological conditions play a major role in the dispersion of pollutants emitted from the refineries in the state of Kuwait (Isakov et al., 2007); the Area under study affected by the effect of sea and land breeze and hence affects the ground level concentration of $\mathrm{SO} 2$ andVOC in the residential areas. A one year hourly record of the surface and upper air meteorological data for year 2006 obtained for Ahmadi and Shuiba refineries is used in this study for simulation of the dispersion of these pollutants from the flares.

The study area consists of $21 \times 24 \mathrm{~km}$ rectangular having all emission sources in the center covering the industrial and urban areas.

The AERMET program is a meteorological preprocessor which prepares hourly surface data and upper air data for use in the U.S. EPA AERMOD short term air quality dispersion model. AERMET processes meteorological data in three stages and from this process two files are generated for use with the AERMOD model:

- A surface file of hourly boundary layer parameter estimates
- A profile files of multiple-level observations of wind speed, wind direction, temperature and standard deviation of the fluctuating wind components

Other assumptions which were used in the AERMOD model include the following:

- Steady state conditions

- emission inventories are time independent

- no interactions among various emission sources

- emission losses due to chemical reaction, absorption or deposition are negligible

- Effects of various structures located in the vicinity of emitting sources have negligible effect

\section{RESULTS AND DISCUSSION}

The emission rates of the point sources, locations and other physical parameters were fed from Al-Ahmadi and Al-suiba refineries. A $500 \mathrm{~km}^{2}$ grid consisting of $21 \times 21$ nodes equally spaced $2.5 \mathrm{~km}$ apart has been selected in combination with a finer grid of 441 receptor locations and 70 discrete most sensitive receptors distributed in the urban areas. The AERMOD model was executed for total $\mathrm{SO}_{2}$ emissions and the impact of predicted ground level concentration in the study area. The model was recomputed with VOCs emissions to asses the impact of ground level concentration of total VOCs in the study area. The AERMOD model results were composed of the maximum ground level concentration of both $\mathrm{SO}_{2}$ and VOCS in the selected grid area. Their emissions impact was assessed for a period of $8760 \mathrm{~h}$ equivalent to one year using hourly synoptic meteorological data for a year 2006. The average hourly, daily and annual maximum ground level concentrations of both $\mathrm{SO}_{2}$ and VOC's were compared with the Kuwait Environmental Public Authority, EPA standards.

The isopleths plot was generated; (Fig. 3) which showed the highest hourly average ground-level concentration of $\mathrm{SO}_{2}$ around the refineries. From the total area under investigation $18 \%$ was above the KEPA limits at immediate neighborhood of the industries, which is $90.25 \mathrm{~km}^{2}, 6.75 \mathrm{~km} \mathrm{E}, 2.5 \mathrm{~km} \mathrm{~W}, 7 \mathrm{~km} \mathrm{~S}$ and $2.5 \mathrm{~km} \mathrm{~N}$ with respect to MAFP flare. Highest maximum concentration predicted hourly of $\mathrm{SO}_{2}$ was $1224.46 \mu \mathrm{g}$ $\mathrm{m}^{3}$ on 15th February at $1.00 \mathrm{AM}$ in south east SE direction with respect to MAFP with distance $5.8 \mathrm{~km}$.

In Kuwait the prevailing wind is almost all the time from north west NW as shown in Fig. 2 confirming the highest ground level $\mathrm{SO}_{2}$ concentration to be the south east SE from the predominate source.

The model was run considering only AL-Shuiba refinery emission sources and its contribution to the highest ground level concentration has been assessed. 


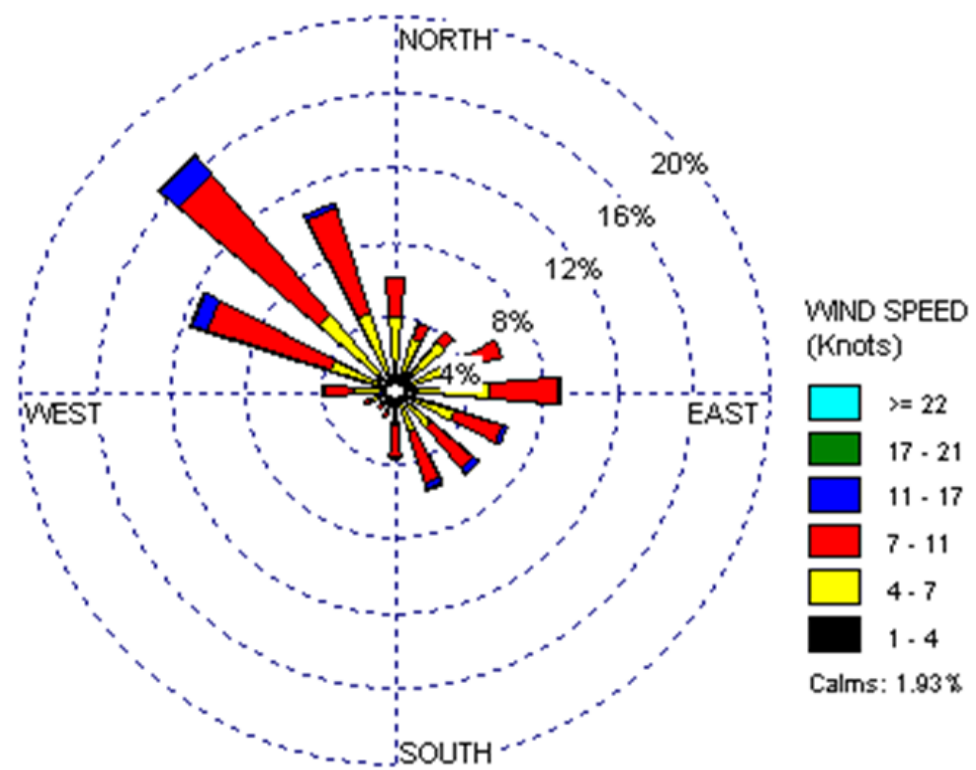

Fig. 2: Wind rose for Coastal Meteorological Data of year 2006 in Kuwait

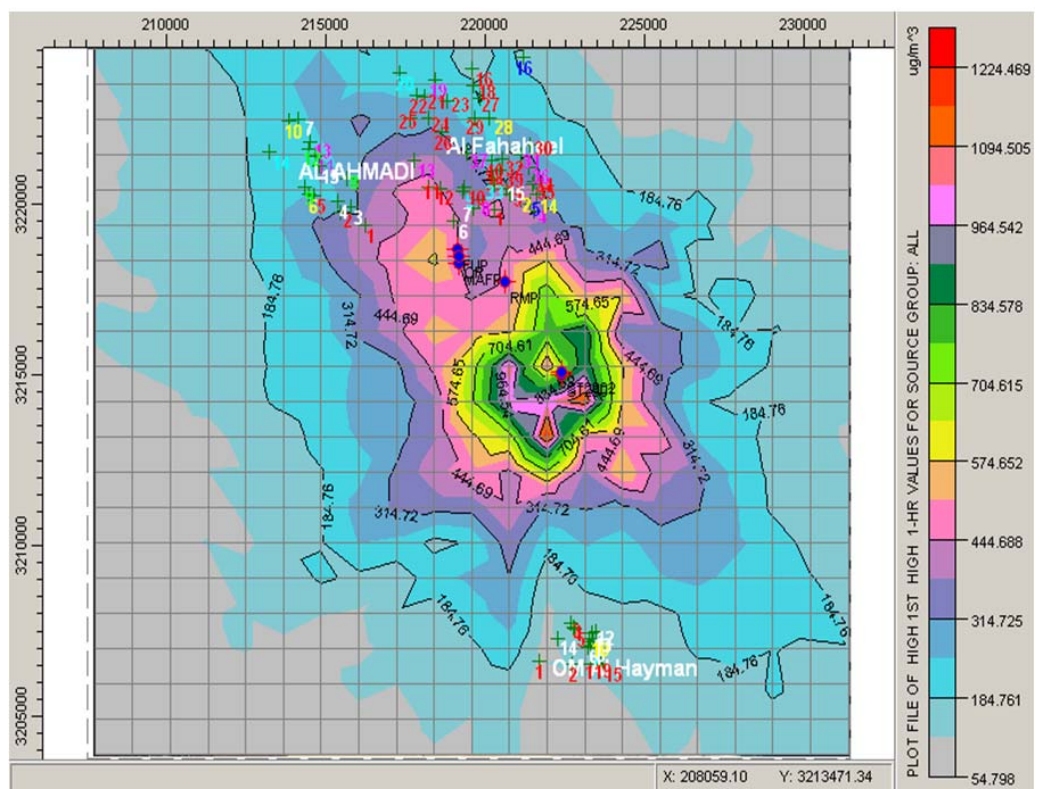

Fig. 3: Isoplath showing the hourly average ground Level $\mathrm{SO}_{2}$ concentration

The first maximum concentration predicted hourly from Al-Shuiba refinery alone was $1219.96 \mu \mathrm{g} \mathrm{m}^{-3}$. And this contributes $99.63 \%$ of the total ground level concentration of $\mathrm{SO}_{2}$ indicating very little impact due to Al-Ahmadi refinery. The average sulfur content in the gas flared from Al-Ahmadi $0.88 \%$ by volume hydrogen sulfide $\mathrm{H}_{2} \mathrm{~S}$ while the average sulfur content of flared gas from Al-Shuiba refinery is $6.1 \%$ by $\mathrm{V} \mathrm{H}_{2} \mathrm{~S}$ showing the predominate influence on ground level concentration.
All the maximum values were in cold months of winter having low temperature and low conversion layer controlling adversely the dispersion phenomena.

Al-Shuiba refinery consists of two refinery stacks, ST29-01 and ST29-02 and AL- Ahmadi refinery consists of four flaring stacks, MAFP, RMP, OR and FUP. We compared between the first maximum concentration predicted hourly of $\mathrm{SO}_{2}$ from individual flares it's found that ST29-01 and ST29-02 of Al-Shuiba refinery have 
Am. J. Environ. Sci., 6 (6): 505-515, 2010

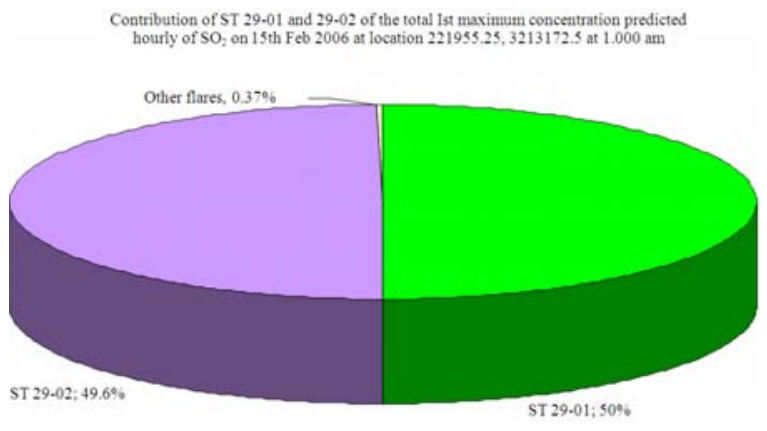

Fig. 4: Contribution of flaring sources in the hourly predicted of the highest maximum ground level concentration of $\mathrm{SO}_{2}$

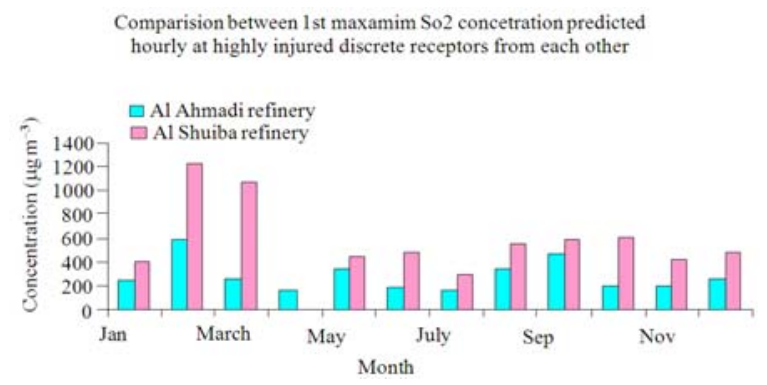

Fig. 5: Comparison of the highest maximum concentration of $\mathrm{SO}_{2}$ predicted hourly from AlAHmadi and Al-Shuiba refineries

the highest impact then MAFP, OR, RMP and FUP due to low sulfur emissions respectively.

Also Fig. 4 illustrated the Contribution of flaring sources in the hourly predicted of the highest maximum ground level concentration of $\mathrm{SO}_{2}$

As shown Fig. 5 the concentrations predicted hourly from AL Shuiba refinery of $\mathrm{SO}_{2}$ is higher than Al Ahmadi refinery in all the months except April where Shuiba refinery was shut down for one month. All the maximum values were in cold months of winter due to low temperature that adversely affected the dispersion phenomena.

The highest maximum concentration predicted daily of SO2 was $177.58 \mu \mathrm{g} \mathrm{m}^{-3}$ which exceed EPA value on 14th February at midnight 24.00 PM in direction south east SE with respect to MAFP with distance $3.4 \mathrm{~km}$ from MAFP flare. It was found that $0.04 \%$ of the total area under investigation was above the KEPA limit which is $0.18 \mathrm{~km}^{2}$ at immediate neighborhood of the industries, that's confirming again the prevailing North West NW wind as indicating in Fig. 6.

Highest maximum concentration predicted annually of $\mathrm{SO}_{2}$ was $9.97 \mu \mathrm{g} / \mathrm{m} 3$ in the direction of south east SE with respect to MAFP with distance 1.8 km as shown in Fig. 7.
Table 1 shows the first maximum concentrations of $\mathrm{SO} 2$ predicted hourly and daily monthly in each month for year 2006. Winter months had high pollutants concentrations than summer months due to the least dispersion influenced by low temperature and low inversion layer. Sometimes the emission rates in summer are high due to the higher capacity of production and market demand that has resulted into higher ground level concentrations as shown in Table 2.

Table 3 showing that the 50 values of maximum concentration of $\mathrm{SO}_{2}$ predicted hourly from Al-Ahmadi and Al-Shuiba Refineries are mostly in south east SE direction as the prevailing wind is almost all the time from north west NW as shown in Fig. 2. Most of the 50 values in winter months at early morning hours.

Highly influenced discrete receptors of the 70 points from $\mathrm{SO}_{2}$ Concentration predicted hourly were number NO.16 (primary school), No.26 (primary school), NO.21 (Ministry of Electricity), NO.19 (Public Park) with concentrations levels 494.15, 480.92, 466.42 and 450.87 $\left(\mu \mathrm{g} \mathrm{m}^{-3}\right)$ respectively. These values exceed EPA and are located in direction NE, NW, NW and NE respectively with respect to reference source MAFP at distance 1.9, $2.4,1.25$ and $2.8 \mathrm{~km}$. These receptors are near to AlAhmadi refinery and has strong influence from AlAhmadi emissions as shown in Fig. 8. The receptor NO.19 (Public Park) has showed high concentration that was influenced from Al-Shuiba refinery on 14th August at 21.00 as the wind direction was from south west SW direction blow up towards Al-Fahaheel area.

The isopleths plot was generated, (Fig. 9) which showed the highest $3 \mathrm{~h}$. maximum ground-level concentrations of VOCs around the refineries. From the total study area under investigation $14.85 \%$ was above the KEPA limits at immediate neighborhood of the industries, which is $74.3 \mathrm{~km}^{2}, \quad 5.5 \mathrm{~km} \mathrm{E}, \quad 5.3 \mathrm{~km}$ $\mathrm{W}, \quad 3.6 \mathrm{~km} \mathrm{~S}$ and $3 \mathrm{~km} \mathrm{~N}$ with respect to MAFP flare. First maximum concentration predicted per $3 \mathrm{HR}$ was $992.4 \mu \mathrm{g} \mathrm{m}^{-3},(0.47 \mathrm{ppm})$ on 14th February at $6.00 \mathrm{am}$ in North West NW direction with respect to MAFP with distance $2 \mathrm{~km}$. because in early morning there is low temperature and low inversion layer. The wind condition is not strongly influencing the plume touchdown which is in the NW $2 \mathrm{~km}$ from MAFP.

The model was run considering only AL-Ahmadi refinery emission sources and its contribution to the highest ground level concentration has been assessed. The first maximum concentration predicted for $3 \mathrm{HR}$ from Al-Ahmadi refinery alone was $935.05 \mu \mathrm{g} \mathrm{m}^{-3}$, $(0.46 \mathrm{ppm})$. And this contributes $99.84 \%$ of the total ground level concentration indicating almost negligible impact due to Al-Shuiba refinery. The average content of $\mathrm{NMHC}$ in the gas flared from Al-Ahmadi refinery is $30 \%$ by $\mathrm{V}$ while the average NMHC content of flared gas from Al-Shuiba refinery is $10.3 \%$ by V showing the predominate influence on ground level concentration. 
Am. J. Environ. Sci., 6 (6): 505-515, 2010

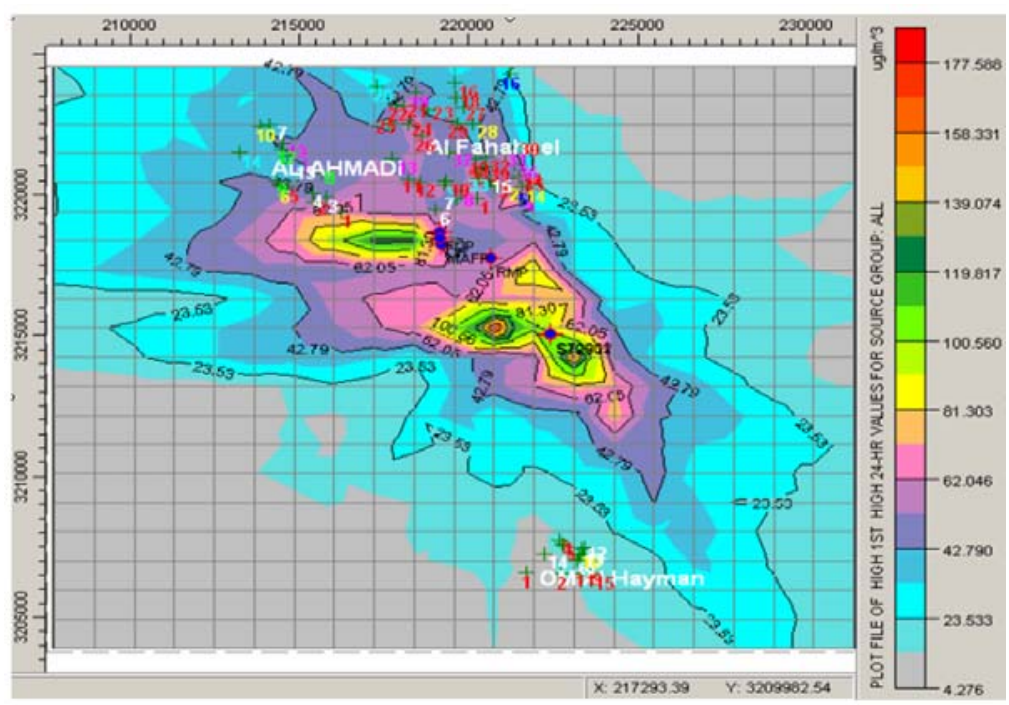

Fig. 6: Isoplath showing the daily maximum average ground Level $\mathrm{SO}_{2}$ concentration

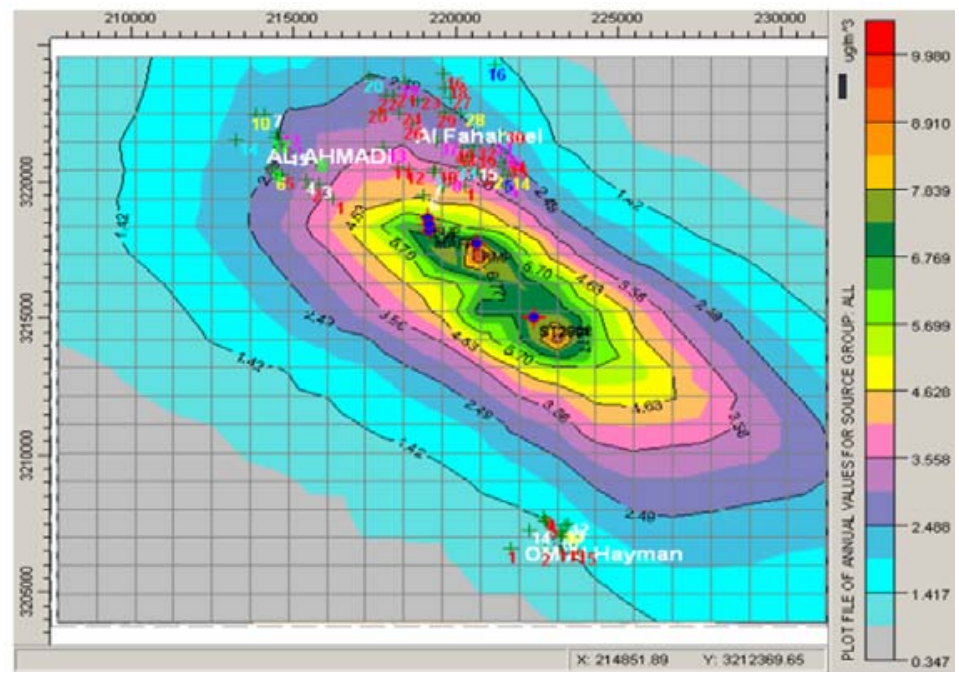

Fig. 7: Isoplath showing the annual maximum average ground Level $\mathrm{SO}_{2}$ concentration

Table 1: First maximum concentrations of $\mathrm{SO}_{2}$ predicted hourly and daily in each month

\begin{tabular}{|c|c|c|c|c|c|c|c|c|}
\hline & $\begin{array}{l}\text { 1st hourly } \\
\left(\mu \mathrm{g} \mathrm{m}^{-3}\right)\end{array}$ & Direction & $\begin{array}{l}\text { Distance } \\
(\mathrm{km})\end{array}$ & Date & $\begin{array}{l}\text { 1st Daily } \\
\left(\mu \mathrm{g} \mathrm{m}^{-3}\right)\end{array}$ & Direction & $\begin{array}{l}\text { Distance } \\
(\mathrm{km})\end{array}$ & Date \\
\hline Jan & 467.39 & $\mathrm{SE}$ & 5.63 & 12/01/2006 01:00 & 38.24 & $\mathrm{SE}$ & 5.63 & $12 / 01 / 200624: 00$ \\
\hline Feb & 1224.5 & SE & 5.76 & 15/02/2006 01:00 & 177.59 & SE & 3.38 & $14 / 02 / 200624: 00$ \\
\hline March & 1080.9 & SE & 3.38 & 04/03/2006 07:00 & 64.20 & SE & 3.38 & 04/03/2006 24:00 \\
\hline April & 168.75 & NW & 2.32 & $20 / 04 / 200622: 00$ & 11.79 & NW & 2.32 & $20 / 04 / 200624: 00$ \\
\hline May & 441.02 & $\mathrm{SE}$ & 4.88 & $12 / 05 / 200621: 00$ & 29.69 & $\mathrm{SE}$ & 4.32 & $06 / 05 / 200624: 00$ \\
\hline June & 484.41 & SE & 4.94 & $08 / 06 / 200622: 00$ & 27.27 & SE & 1.99 & $18 / 06 / 200624: 00$ \\
\hline July & 296.56 & SE & 6.51 & $21 / 07 / 200621: 00$ & 33.68 & SE & 5.63 & 07/07/2006 24:00 \\
\hline Aug & 548.21 & SE & 4.88 & 17/08/2006 01:00 & 56.09 & SE & 4.94 & $13 / 08 / 200624: 00$ \\
\hline Sep & 646.80 & $\mathrm{SE}$ & 5.63 & 17/09/2006 21:00 & 40.16 & SE & 5.63 & $17 / 09 / 200624: 00$ \\
\hline Oct & 605.09 & SE & 4.94 & 23/10/2006 01:00 & 70.26 & SE & 4.94 & $22 / 10 / 200624: 00$ \\
\hline Nov & 439.11 & SE & 5.63 & 13/11/2006 07:00 & 38.38 & $\mathrm{SE}$ & 5.63 & 06/11/2006 24:00 \\
\hline Dec & 482.35 & SE & 4.94 & $15 / 12 / 200620: 00$ & 45.85 & SE & 1.83 & $31 / 12 / 200624: 00$ \\
\hline
\end{tabular}


Am. J. Environ. Sci., 6 (6): 505-515, 2010

All maximum values of VOC concentrations were in cold months of winter facilitated by low temperature and low inversion layer controlling adversely the dispersion phenomena.

1st maximum concentration predicted daily of VOC was $260.16 \mu \mathrm{g} \mathrm{m}^{-3}$ on 14th February at 24.00 PM in North West NW direction with respect to MAFP at a distance $8 \mathrm{~km}$ (Fig. 10).

Highest maximum concentration predicted annually of VOC was $15.33 \mu \mathrm{g} \mathrm{m}^{-3}$ in the North West NW direction with respect to MAFP at distance $1 \mathrm{~km}$. (Fig. 11).

Table 4 show the maximum concentrations of VOC predicted per 3HR and daily for each month of year 2006.

Table 6 show the 50 maximum concentration of VOC predicted hourly from Al-Ahmadi and Al-Shuiba Refineries. From the 50 maximum concentrations of VOC predicted per $3 \mathrm{HR}$ we found only 14 values exceed EPA standards for $6.00-9.00 \mathrm{~h}$ while all other high concentration values were almost from 21.00-24.00 h.

Discrete receptors located at schools, clinics, shopping malls showed the highest VOCs concentrations at 21.00-24.00 HR in September month as indicated at Table 7, this due the high emissions rate from OR flare as indicating in Table 5.

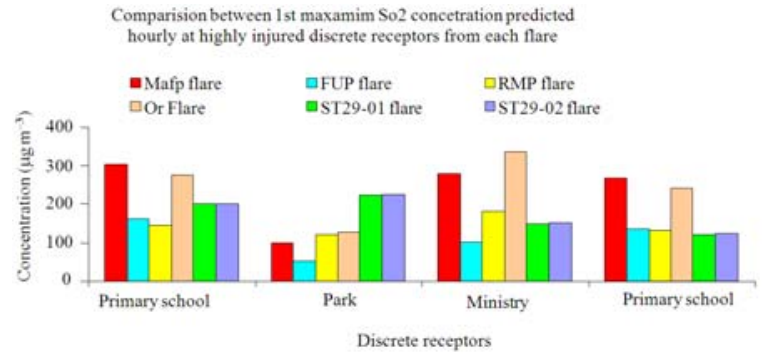

Fig. 8: Individual flares impact on highly influenced discrete receptors

Table 2: Influence of different flares on predicted first maximum ground level concentration of $\mathrm{SO}_{2}$

\begin{tabular}{lll}
\hline & $\begin{array}{l}\text { Month of highest max } \\
\text { Conc. of } \mathrm{SO}_{2} \text { hourly }\end{array}$ & $\begin{array}{l}\text { Month of highest } \\
\max \text { Conc. of } \mathrm{SO}_{2} \text { daily }\end{array}$ \\
\hline Real Situation & Feb & Feb \\
Ahmadi Refinery & Feb & Feb \\
Shuiba Refinery & Feb & Feb \\
MAFP & Feb & Feb \\
FUP & Feb & Feb \\
RMP & Dec & Dec \\
OR & Sep & Sep \\
ST29_01 & Feb & Feb \\
ST29_02 & Feb & Fe \\
\hline
\end{tabular}

Table 3: The 50 maximum concentrations of $\mathrm{SO}_{2}$ predicted hourly from both Al-Ahmadi and Al-Shuiba Refineries

\begin{tabular}{|c|c|c|c|c|c|c|c|c|}
\hline \multirow{3}{*}{$\begin{array}{l}\text { The maximum } \\
501 \text {-HR average } \\
\text { concentration values of } \\
\mathrm{SO}_{2} \text { for source group: } \\
\text { both Ahmadi and Shuiba } \\
\text { refineries }\left(\mu \mathrm{g} \mathrm{m}^{-3}\right)\end{array}$} & \multirow[b]{3}{*}{$\begin{array}{l}\text { Date } \\
\text { (YYMMDDHH) }\end{array}$} & & \multicolumn{4}{|l|}{ The maximum } \\
\hline & & & & & $\begin{array}{l}501-\mathrm{HR} \text { average } \\
\text { concentration values of }\end{array}$ & & Receptor & tion \\
\hline & & $\begin{array}{l}\text { Distance } \\
(\mathrm{km})\end{array}$ & Direction & Rank & $\begin{array}{l}\text { both Ahmadi and Shuiba } \\
\text { refineries }\left(\mu \mathrm{g} \mathrm{m}^{-3}\right)\end{array}$ & $\begin{array}{l}\text { Date } \\
\text { (YYMMDDHH) }\end{array}$ & $\begin{array}{l}\text { Distance } \\
(\mathrm{km})\end{array}$ & Direction \\
\hline 1224.5 & 06021501 & 5.7 & SE & 26 & 604.50 & 06030420 & 4.4 & SE \\
\hline 1169.4 & 06021222 & 5.6 & SE & 27 & 594.46 & 06021219 & 5.6 & SE \\
\hline 1121.1 & 06021218 & 5.6 & SE & 28 & 591.21 & 06021402 & 7.9 & NW \\
\hline 1080.9 & 06030407 & 3.4 & SE & 29 & 588.85 & 06090124 & 3.4 & SE \\
\hline 1065.2 & 06021402 & 3.4 & SE & 30 & 583.04 & 06030421 & 5.9 & SE \\
\hline 1023.1 & 06031406 & 4.9 & SE & 31 & 581.55 & 06102223 & 4.9 & SE \\
\hline 999.48 & 06031902 & 4.3 & SE & 32 & 581.33 & 06102224 & 4.9 & SE \\
\hline 909.95 & 06022201 & 4.4 & SE & 33 & 578.39 & 06021222 & 7.9 & SE \\
\hline 909.65 & 06033023 & 5.8 & SE & 34 & 573.11 & 06022805 & 2.8 & NE \\
\hline 889.22 & 06030421 & 4.9 & SE & 35 & 570.33 & 06030724 & 6.5 & SE \\
\hline 795.73 & 06022804 & 3.4 & SE & 36 & 565.42 & 06022320 & 5.2 & SE \\
\hline 775.42 & 06022704 & 3.4 & SE & 37 & 562.45 & 06090923 & 5.7 & SE \\
\hline 760.41 & 06022805 & 2.9 & SE & 38 & 559.01 & 06022222 & 5.1 & SE \\
\hline 719.88 & 06021406 & 3.4 & SE & 39 & 548.88 & 06022124 & 3.4 & SE \\
\hline 707.55 & 06022124 & 2.9 & SE & 40 & 548.21 & 06081701 & 4.8 & SE \\
\hline 694.57 & 06031807 & 4.1 & SE & 41 & 544.65 & 06030719 & 2.5 & SE \\
\hline 690.80 & 06021501 & 6.7 & SE & 42 & 543.63 & 06021406 & 2.1 & SW \\
\hline 668.34 & 06020419 & 5.3 & SE & 43 & 528.41 & 06022201 & 5.2 & SE \\
\hline 666.16 & 06030407 & 3.1 & SE & 44 & 527.38 & 06021406 & 7.9 & NW \\
\hline 646.79 & 06091721 & 5.7 & SE & 45 & 525.81 & 06021423 & 3.4 & SE \\
\hline 639.38 & 06091302 & 5.7 & SE & 46 & 523.69 & 06091223 & 4.9 & SE \\
\hline 633.64 & 06022222 & 4.3 & SE & 47 & 523.13 & 06093023 & 4.9 & SE \\
\hline 632.86 & 06030406 & 5.3 & SE & 48 & 521.80 & 06030720 & 4.1 & SE \\
\hline 610.65 & 06031402 & 4.4 & SE & 49 & 519.34 & 06022320 & 4.4 & SE \\
\hline 605.09 & 06102301 & 4.9 & SE & 50 & 508.10 & 06101105 & 3.4 & SE \\
\hline
\end{tabular}


Am. J. Environ. Sci., 6 (6): 505-515, 2010

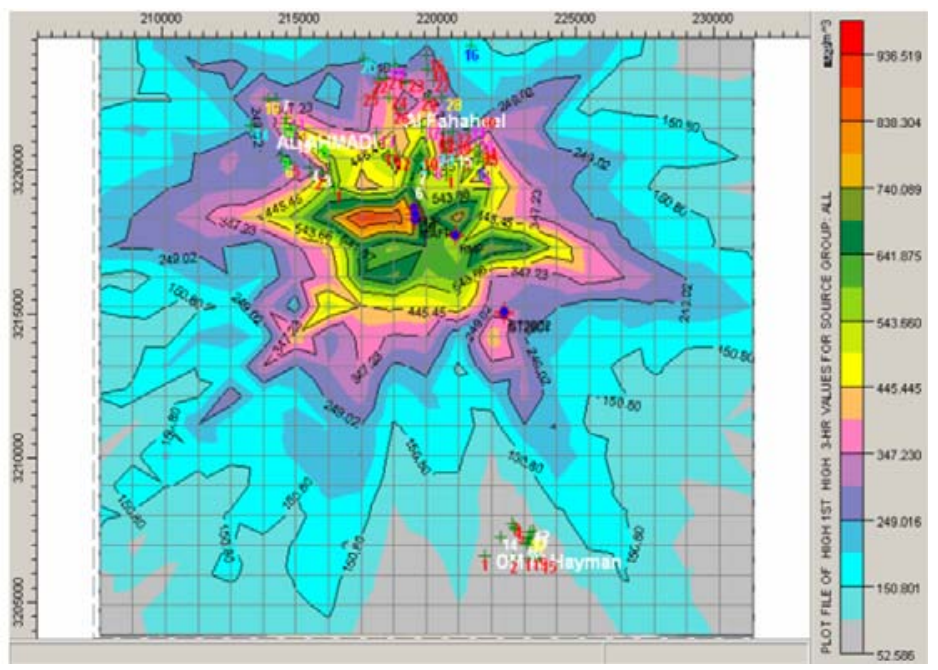

Fig. 9: Isoplath showing the maximum $3 \mathrm{HR}$ average ground Level VOC concentrations

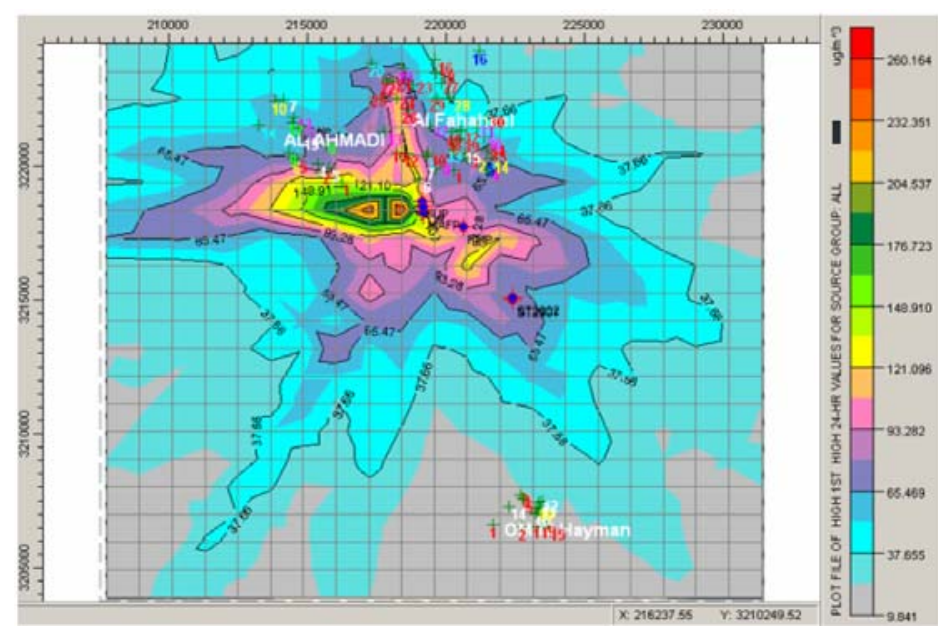

Fig. 10: Isoplath showing the daily maximum average ground Level VOC concentration



Fig. 11: Isoplath showing the annual maximum average ground Level VOC concentration 
Am. J. Environ. Sci., 6 (6): 505-515, 2010

Table 4: Maximum concentrations of VOC predicted per 3HR and daily for each month of year 2006

\begin{tabular}{|c|c|c|c|c|c|c|c|c|c|c|}
\hline & $\begin{array}{l}\text { 1st 3HR } \\
\left(\mu \mathrm{g} \mathrm{m}^{-3}\right) \\
\end{array}$ & $\mathrm{ppm}$ & Direction & $\begin{array}{l}\text { Distance } \\
(\mathrm{km})\end{array}$ & Date & $\begin{array}{l}\text { 1st Daily } \\
\left(\mu \mathrm{g} \mathrm{m}^{-3}\right)\end{array}$ & $\mathrm{ppm}$ & Direction & $\begin{array}{l}\text { Distance } \\
(\mathrm{km})\end{array}$ & Date \\
\hline Jan & 370.27 & 0.19 & $\mathrm{NE}$ & 1.6 & $05 / 01 / 200624: 00$ & 81.85 & 0.04 & NW & 1.3 & 11/01/2006 24:00 \\
\hline Feb & 936.52 & 0.47 & NW & 1.9 & 14/02/2006 06:00 & 260.16 & 0.13 & NW & 0.8 & 14/02/2006 24:00 \\
\hline March & 707.11 & 0.36 & SW & 2.1 & $30 / 03 / 200624: 00$ & 98.26 & 0.05 & SW & 2.1 & $30 / 03 / 200624: 00$ \\
\hline April & 624.37 & 0.31 & NW & 1.9 & 11/04/2006 06:00 & 127.75 & 0.06 & NW & 2.3 & 20/04/2006 24:00 \\
\hline May & 533.76 & 0.27 & NW & 1.2 & 26/05/2006 24:00 & 109.07 & 0.05 & SE & 1.1 & $26 / 05 / 200624: 00$ \\
\hline June & 322.28 & 0.16 & NW & 1.4 & 06/06/2006 24:00 & 54.76 & 0.03 & $\mathrm{NE}$ & 1.9 & 05/06/2006 24:00 \\
\hline July & 323.42 & 0.16 & SE & 2.9 & 21/07/2006 21:00 & 66.91 & 0.03 & SE & 1.1 & 05/07/2006 24:00 \\
\hline Aug & 497.46 & 0.25 & NW & 1.3 & 27/08/2006 24:00 & 124.36 & 0.06 & NW & 1.2 & 27/08/2006 24:00 \\
\hline Sep & 774.62 & 0.39 & $\mathrm{NE}$ & 1.6 & 08/09/2006 03:00 & 121.79 & 0.06 & SE & 2.9 & $13 / 09 / 200624: 00$ \\
\hline Oct & 362.55 & 0.18 & NW & 2.4 & 08/10/2006 24:00 & 71.93 & 0.04 & NW & 4.4 & $21 / 10 / 200624: 00$ \\
\hline Nov & 328.74 & 0.17 & SE & 1.8 & $11 / 11 / 200624: 00$ & 56.44 & 0.03 & SE & 1.9 & $11 / 11 / 200624: 00$ \\
\hline Dec & 290.81 & 0.15 & NW & 1.4 & 06/12/2006 03:00 & 62.18 & 0.03 & NW & 2.9 & 05/12/2006 24:00 \\
\hline
\end{tabular}

Table 5: Influence of different flares on predicted first maximum ground level concentration of VOC

\begin{tabular}{ll}
\hline & Month of 1st max Conc of VOC 3 HRS \\
\hline Real Situation & Feb \\
Al-Ahmadi refinery & Feb \\
Al-Shuiba refinery & Feb \\
MAFP & Feb \\
FUP & Nov \\
RMP & Dec \\
OR & Sep \\
ST29_01 & Feb \\
ST29_02 & Feb \\
\hline
\end{tabular}

Table 6: 50 maximum concentration of VOC predicted hourly from Al-Ahmadi and Al-Shuiba Refineries

\begin{tabular}{|c|c|c|c|c|c|c|c|c|c|c|}
\hline The maximu & & & & & & The maxi & & & & \\
\hline $501-\mathrm{HR}$ ave & & & & & & $501-\mathrm{HR}$ a & & & & \\
\hline concentratio & & & & & & concentrat & & & & \\
\hline values of $\mathrm{VC}$ & & & & & & values of & & & & \\
\hline for source $g_{1}$ & & & & & & for source & & & & \\
\hline both Ahmad & & & & & & both Ahm & & & & \\
\hline and Shuiba & & & & & & and Shuib & & & & \\
\hline $\begin{array}{l}\text { refineries } \\
\left(\mu \mathrm{g} \mathrm{m}^{-3}\right)\end{array}$ & ppm & $\begin{array}{l}\text { Date } \\
\text { (YYMMDDHH) }\end{array}$ & $\begin{array}{l}\text { Distance } \\
(\mathrm{km})\end{array}$ & Direction & Rank & $\begin{array}{l}\text { refineries } \\
\left(\mu \mathrm{g} \mathrm{m}^{-3}\right)\end{array}$ & ppm & $\begin{array}{l}\text { Date } \\
\text { (YYMMDDHH) }\end{array}$ & $\begin{array}{l}\text { Distance } \\
(\mathrm{km})\end{array}$ & Direction \\
\hline 936.51 & 0.47 & 06021406 & 1.9 & NW & 26 & 567.95 & 0.29 & 06021406 & 4.3 & NW \\
\hline 897.75 & 0.45 & 06021406 & 0.8 & NW & 27 & 567.64 & 0.29 & 06042024 & 2.5 & NW \\
\hline 774.61 & 0.39 & 06090803 & 1.6 & $\mathrm{NE}$ & 28 & 567.33 & 0.29 & 06091706 & 0.4 & $\mathrm{NE}$ \\
\hline 736.14 & 0.37 & 06090803 & 2.9 & SE & 29 & 565.48 & 0.28 & 06091721 & 3.2 & NW \\
\hline 724.41 & 0.36 & 06021406 & 3.1 & NW & 30 & 562.59 & 0.28 & 06040103 & 1.8 & SE \\
\hline 707.11 & 0.36 & 06033024 & 2.1 & SW & 31 & 560.34 & 0.28 & 06091721 & 3.3 & NW \\
\hline 703.28 & 0.35 & 06091706 & 1.5 & NE & 32 & 558.68 & 0.28 & 06041921 & 3.9 & NW \\
\hline 687.58 & 0.35 & 06090803 & 4.1 & SE & 33 & 547.49 & 0.28 & 06090921 & 3.3 & $\mathrm{NE}$ \\
\hline 682.63 & 0.34 & 06021403 & 0.8 & NW & 34 & 540.92 & 0.27 & 06041921 & 4.3 & NW \\
\hline 682.06 & 0.34 & 06090124 & 2.1 & $\mathrm{NE}$ & 35 & 539.58 & 0.27 & 06093024 & 2 & $\mathrm{NE}$ \\
\hline 667.11 & 0.34 & 06090806 & 2.2 & SW & 36 & 534.94 & 0.27 & 06091921 & 2.2 & $\mathrm{NE}$ \\
\hline 664.06 & 0.33 & 06090124 & 2.2 & NE & 37 & 533.76 & 0.27 & 06052624 & 1.3 & NW \\
\hline 656.12 & 0.33 & 06030406 & 2.8 & SW & 38 & 529.63 & 0.27 & 06090321 & 1.5 & $\mathrm{NE}$ \\
\hline 644.48 & 0.32 & 06090921 & 2.7 & $\mathrm{NE}$ & 39 & 529.36 & 0.27 & 06030406 & 4.4 & SW \\
\hline 634.24 & 0.32 & 06091221 & 1.2 & NW & 40 & 528.93 & 0.27 & 06021224 & 2.5 & SE \\
\hline 632.29 & 0.32 & 06090803 & 0.4 & $\mathrm{NE}$ & 41 & 528.37 & 0.27 & 06091924 & 1.6 & $\mathrm{NE}$ \\
\hline 631.92 & 0.32 & 06090306 & 1.1 & $\mathrm{SE}$ & 42 & 528.24 & 0.27 & 06091224 & 3 & $\mathrm{NE}$ \\
\hline 624.37 & 0.31 & 06041106 & 2 & NW & 43 & 522.01 & 0.26 & 06090124 & 1.3 & NW \\
\hline 613.16 & 0.31 & 06090306 & 2.5 & SE & 44 & 520.96 & 0.26 & 06090921 & 3.3 & $\mathrm{NE}$ \\
\hline 598.17 & 0.3 & 06021403 & 2 & NW & 45 & 520.01 & 0.26 & 06090921 & 3.2 & $\mathrm{NE}$ \\
\hline 595.56 & 0.3 & 06042024 & 2.3 & NW & 46 & 519.55 & 0.26 & 06091303 & 2.9 & SE \\
\hline 590.11 & 0.3 & 06090124 & 2.2 & $\mathrm{NE}$ & 47 & 517.69 & 0.26 & 06091221 & 2.1 & $\mathrm{NE}$ \\
\hline 576.38 & 0.29 & 06031406 & 2 & SE & 48 & 514.99 & 0.26 & 06091224 & 1.9 & $\mathrm{NE}$ \\
\hline 575.56 & 0.29 & 06041724 & 1 & SE & 49 & 508.80 & 0.26 & 06090803 & 5.2 & SE \\
\hline 573.82 & 0.29 & 06030406 & 1.2 & SW & 50 & 499.52 & 0.25 & 06090724 & 1.8 & SE \\
\hline
\end{tabular}


Am. J. Environ. Sci., 6 (6): 505-515, 2010

Table 7: Highly influnced discrete receptors from VOC ground level concentrations for $3 \mathrm{~h}$

\begin{tabular}{lllllll}
\hline Area & Type & Distance $(\mathrm{km})$ & Direction & 1st-3HR Conc. & ppm & Date (YYMMDDHH) \\
\hline Al Fahaheel & Clinic & 2.1 & NE & 682.06 & 0.343 & 06090124 \\
Al Fahaheel & Primary school & 2.2 & NE & 664.06 & 0.334 & 06090124 \\
Al Fahaheel & Mall & 2.7 & NE & 644.48 & 0.324 & 06090921 \\
Al Fahaheel & Ministery & 1.2 & NW & 634.24 & 0.319 & 06091221 \\
Al Fahaheel & Primary school & 2.5 & NW & 567.64 & 0.285 & 06042024 \\
Al Ahmadi & Seconday school & 3.2 & NW & 565.48 & 0.284 & 06091721 \\
Al Fahaheel & Nursery & 3.3 & NE & 547.47 & 0.275 & 06090921 \\
Al Ahmadi & Mosque & 4.3 & NW & 540.92 & 0.272 & 06041921 \\
Al Fahaheel & Seconday school & 1.9 & NE & 539.58 & 0.271 & 06093024 \\
Al Fahaheel & Primary school & 3.4 & NE & 520.96 & 0.262 & 06090921 \\
Al Fahaheel & Mall & 3.2 & NE & 520.01 & 0.261 & 06090921 \\
Al Fahaheel & Homes & 1.6 & NE & 489.86 & 0.246 & 06091921 \\
Al Fahaheel & Hotel & 2.8 & NE & 488.66 & 0.246 & 06090921 \\
\hline
\end{tabular}

\section{CONCLUSION}

- $\mathrm{Al}$ shuiba refinery contributes $99.63 \%$ of the total ground level concentration of $\mathrm{SO}_{2}$ indicating very little impact due to Al-Ahmadi refinery. The average sulfur content in the gas flared from AlAhmadi $0.88 \%$ by $\mathrm{V}$ hydrogen sulfide $\mathrm{H}_{2} \mathrm{~S}$ while the average sulfur content of flared gas from AlShuiba refinery is $6.1 \% \quad \mathrm{~V} \mathrm{H}_{2} \mathrm{~S}$ showing the predominate influence on ground level concentration

- AL-Ahmadi refinery contributes $99.84 \%$ of the total ground level concentration of NMHC indicating very little impact due to Al-Shuiba refinery. The average content of NMHC in the gas flared from Al-Ahmadi refinery is $30 \% \mathrm{~V}$, while the average NMHC content of flared gas from AlShuiba refinery is $10.3 \% \mathrm{~V}$ reflecting the predominate influence on ground level concentration

- In Kuwait the prevailing wind is almost all the time from north west NW confirming the highest ground level $\mathrm{SO}_{2}$ concentration to be the south east $\mathrm{SE}$ from the predominate source

- All the maximum values were in cold months of winter having low temperature and low inversion layer controlling adversely the dispersion phenomena. In the month of September there were high emissions of VOCs from Al-Ahmadi refinery producing high level concentrations at various discrete receptors

- About 50 maximum highest values of $\mathrm{SO}_{2}$ exceeded EPA standards at locations within $4-5 \mathrm{~km}$ around sources.

- From the 50 maximum concentrations of VOC predicted per $3 \mathrm{HR}$ we found only 14 values exceed EPA standards for 6.00-9.00 h while all other high concentration values were almost from 21.00-24.00 h
- Model validation with actual ground level measurements can authenticate the results and application of model including all emission sources can provide exact gas concentrations in and around the petroleum refineries

\section{ACKNOWLEDGMENT}

Sincere appreciation and gratitude to Dr. Mufreh Saeed Al Rashidi from Environment and Urban Development Division, Costal and Air Pollution Department in Kuwait's Institute for Scientific Research (KISR), for his valuable insight and generous help in the AERMOD model operation and processing Meteorological data. I would like also to thank, Eng. Ghalia Al-Azmi, from Kuwait's National Petroleum Company, KNPC for her valuable help.

\section{REFERENCES}

Abdul-Wahba, S.A.A., S.M. Al-Alwi and A. ElZawahry, 2002. Patterns of $\mathrm{So}_{2}$ emissions: a refinery case study, Environ. Mod. Software, 17: 563-570. DOI: 10.1016/S1364-8152(02)00023-3

Al-Hamad, K.K. and A.R. Khan, 2008. Total emission from flaring in Kuwait Oil fields. Am. J. Environ. Sci., 4: 31-38.

Al-Jahdali, M.O. and A.S.B. Bisher, 2008. Sulfur dioxide $\left(\mathrm{SO}_{2}\right)$ accumulation in soil and plant's leaves around an oil refinery: A case study from Saudi Arabia. Am. J. Environ. Sci., 4: 84-88. DOI: 10.3844/ajessp.2008.84.88

Cetin, E., M. Odabasi and R. Seyfioglu, 2003. Ambient Volatile Organic Compound (VOC) concentrations around a petrochemical complex and a petroleum refinery. Sci. Total Environ., 312: 103-112. DOI: 10.1016/S0048-9697(03)00197-9

Holmes, N.S. and L. Morawska, 2006. A review of dispersion modeling and its application to dispersion of particles: An overview of different dispersion models available. Atmospheric Environ., 40: 5902-5928. 
Isakov, V., A. Venkatram, J.S. Touma, D. Koracin and T.L. Otte, 2007. Evaluating the use of outpiuts from comprehensive meteorological models in air quality modeling applications. Atmospheric Environ., 41: 1689-1705. DOI: 10.1016/j.atmosenv.2006.10.043

Kalabokas, P.D., J. Hatzianestis, J.G. Bartzis and P. Papagiannakopoulos, 2001. Atmospheric concentrations of saturated and aromatic hydrocarbons around a Greek oil refinery, Atmospheric Environ., 35: 2545-2555. DOI: 10.1016/S1352-2310(00)00423-4

Kesarkar, A.P., M. Dalvi, A. Kaginalkar and A. Ojha, 2007. Coupling of the weather research and forecasting model with AERMOD for pollutant dispersion modeling. A case study for PM10 dispersion over Pune, India. Atmospheric Environ., 41: 1976-1988. DOI: 10.1016/j.atmosenv.2006.10.042
Ramadan, A.A., M. Al-Sudairawi, S. Alhajraf and A.R. Khan, 2008. Total $\mathrm{SO}_{2}$ emissions for power stations and evaluation of their impact in kuwait using gaussian plume dispersion model. Am. J. Environ. Sci., 4: 1-12.

Venkatram, A., V. Isakov, J. Yuan and D. Pankratz, 2004. Modeling dispersion at distance of meters from urban sources. Atmospheric Environ., 38: 4633-4641. 